The Geographical Journal of Nepal

Vol. 13: 47-68, 2020

Doi: http://doi.org/10.3126/gjn.v13i0.28151

Central Department of Geography,

Tribhuvan University, Kathmandu, Nepal

\title{
Evolution of cartographic aggression by India: A study of Limpiadhura to Lipulek
}

\author{
Jagat K. Bhusal \\ Professional Hydrologist (PEng) and Ex-Chairman of ETFC. \\ Email: bhusaljagat@gmail.com
}

Received: 8 November 2019; Accepted: 22 January 2020; Published: March 2020

\begin{abstract}
Nepal is a sovereign country since its history and has never been colonized. In course of time, once a greater Nepal shrunk to present territory after its defeat in the AngloNepal War (1814-15) and since the signing of the border treaty (Between the East India Company and the Raja of Nepal) which is known as the Sugauli Treaty of 1816. The defeat fixed the river Kali as the border in the west and the Mechi in the east on the hilly regions whereas there are border pillars (Jange Pillars) on the southern plains. The territorial issue between Nepal and India on the north-west border, especially up to the source of the Kali river is reviewed in this paper. Interpretations of the relevant documents and correspondences, reviewed papers, articles in periodicals and newspapers, and historical maps are critically made with reference to the recent freely available google maps and political maps published by Nepal and India. British-India after the Sugauli treaty and also India after the independence realized the importance of the Gunji-Kuti area, Lipulek pass and Kalapani and made the unilateral cartographic manipulation on the North-west border of Nepal. It is found that the borderline swinging over the century clearly indicated that the encroachment of about $400 \mathrm{sq} . \mathrm{km}$ land of Nepal contravened the spirit of the Sugauli Treaty.
\end{abstract}

Keywords: Sugauli treaty, Kalapani, Fictitious border, Phantom location, Cartographic manipulation,

\section{Background}

The publication of its political map by India in November 2019 that shows the Nepalese land in the far western part of the country, Limpiadhura, Lipulek, and Kalapani, as its territory has once again brought back to the boundary encroachment of Nepal in the area 
east of the Kali (Mahakali River/Sarada River), the boundary between the two countries as per the Treaty of Sugauli-1816, by the southern neighbor since the time of British India into fore. The ongoing territorial issue between Nepal and India involving some 400 sq. km sovereign land of Nepal on the north-west border, especially the source of the Mahakali river, in fact, dates back to the Sugauli Treaty of 1816 signed between the East India Company of Great Britain and the Raja of Nepal. It may be added that India's recently (2019) published its new political map showing the said amount of Nepali land within her territory when her government had, time and again, admitted that the upper reaches of Kali are disputed (Bhandari, 2015; Dhungel \& Pun, 2014; JWG, 1998; Rajan, 2000; Risal, 1999; Dhungel, 1999). This paper is digging out the cartographic aggression of India focused on the issues related to the encroachment on the North-West border of Nepal.

\section{Nepal: Location from the border perspective}

Nepal falls over the Himalayan region which was formed about 75 million years ago when the Indian plate collided with the Eurasian plate. Nepal lies almost completely within the collision zone (Ali \& Aitchison, 2005). It is a landlocked country located between India and the Tibetan Autonomous Region of China. It is located between $26^{\circ} 22^{\prime}$ to $30^{\circ} 27^{\prime}$ North latitudes and $80^{\circ} 04^{\prime}$ to $88^{\circ} 12^{\prime}$ East longitudes, and extends about 800 kilometers East-West and 150 to 250 kilometers North-South with an area of 147,181 sq. km (Figure 1).

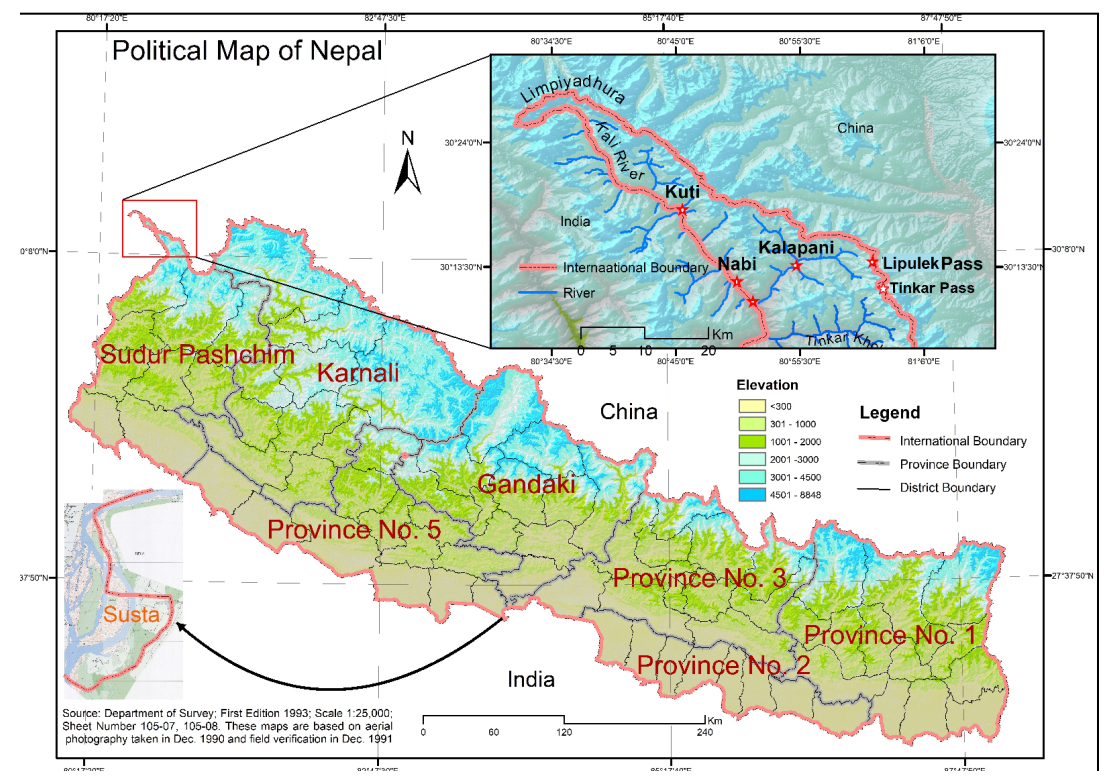

Figure 1: Nepal and location of disputed (encroached) area (Map by Gurung, 2019). 
In the latter half of the $18^{\text {th }}$ century Prithvi Narayan Shah, the ruler (1768-1775) of the Kingdom of Gorkha, formed a unified country of Nepal by conquering several independent states (Sodari, 2020). His successors extended its territory up to Kangra to the west including the Kumaon and Garhwal and up to Testa, Sikkim in the east (Regmi, 1958; Manandhar, 1983). In India, the East-India British Company while expanding its territory felt the necessity of routes to Tibet as well as of the forest resources of Nepal and so declared the war with Nepal. (kullabs.com/classes/subjects/units/lessons/ notes/note-detail/693-). When the war between the two countries was going on, Francis Rawdon-Hastings, 1st marquess of Hastings (2nd Lord Moire), the Governor General of India had sent a secret letter to the Secret Committee of the East India Company, London on June 1, 1815, suggesting the Kali River to be the eastern boundary of East India with Nepal (Cox, 1824). The defeat of Nepal in the war (1814-15) with the British, Nepal was compelled to sign 'The Treaty of Sugauli in 1816' which shrunk Nepal's territory to the current shape.

Article 5 of the Sugauli Treaty between the East India Company and Nepal states that,

'the Rajah of Nepal renounces for himself, his heirs, and successors, all claim to or connexion with the countries lying to the west of the River Kali and engages never to have any concern with those countries or the inhabitants thereof' (Bhandari, pp. 282-300).

But later on, Nepal was able to get back some of her southern plain lands in two phases, i.e. a first return of the eastern Tarai on 11 December 1816, and second return of four districts of Banke, Bardiya, Kailali, and Kanchanpur of Western Tarai on November 1, 1860 (Paudyal, 2013). The British Government signed a treaty of friendship in 1923. Nepal established diplomatic relations with would-be independent India on 17 June 1947 and a friendship treaty in 1950 with Independent India. Nepal established diplomatic relations with the People's Republic of China on 1 August 1955 and signed the Treaty of Peace and Friendship in 1960. Nepal joined the United Nations on 14 December 1955 (Acharya, 2013). It stands as a buffer state between China and India.

\section{Borderline-1 by Sugauli treaty of 1816}

The map published by the East India Company after the Treaty of Sugauli on January 2, 1816 , is the medium-scale map (Figure 2) that showed the pictorial interpretation of the secret letter of Lord Moira in 1815 (Cox, 1824). 
The secret letter states that,

'the eastern boundary will be the Kali, which rises in the snowy mountains, and pursues nearly a direct southerly course to the plains, where it assumes the name of the Gogra'. 'The Kali forms a well-defined boundary from the snowy mountains to the plains, and though narrow, it is deep and rapid. The snowy range inclining towards the south reaches its extreme point in the direction where it touches the eastern confines of Kumaon. Hence this is the shortest, and consequently the most defensible line of frontier.'

The mapping technology during that time was not as advanced as of today, so the demarcation of the location of the source of the uppermost river reaches of the main Kali river is shown inside the overshadowing area of snow and glaciers in the map.

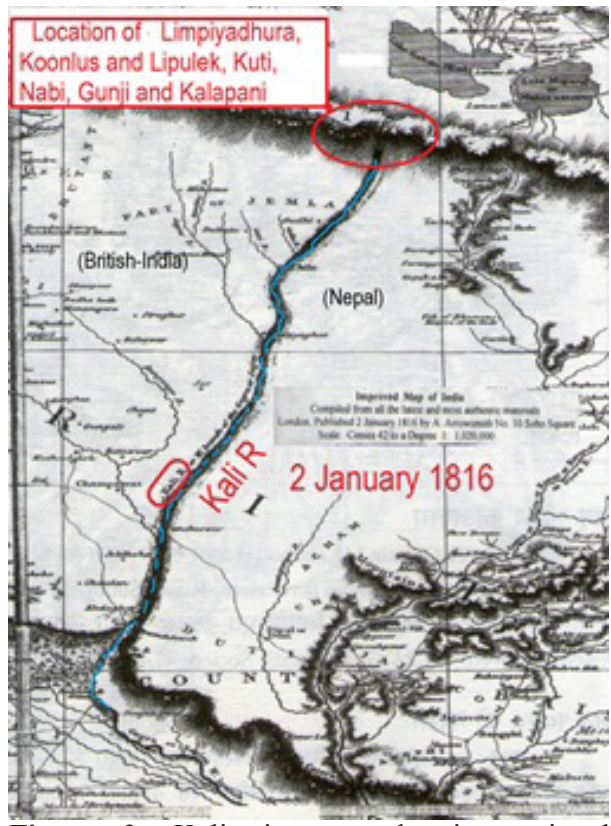

Figure 2: Kali river as the international borderline between British-India and Nepal (www.davidrumsey.com)

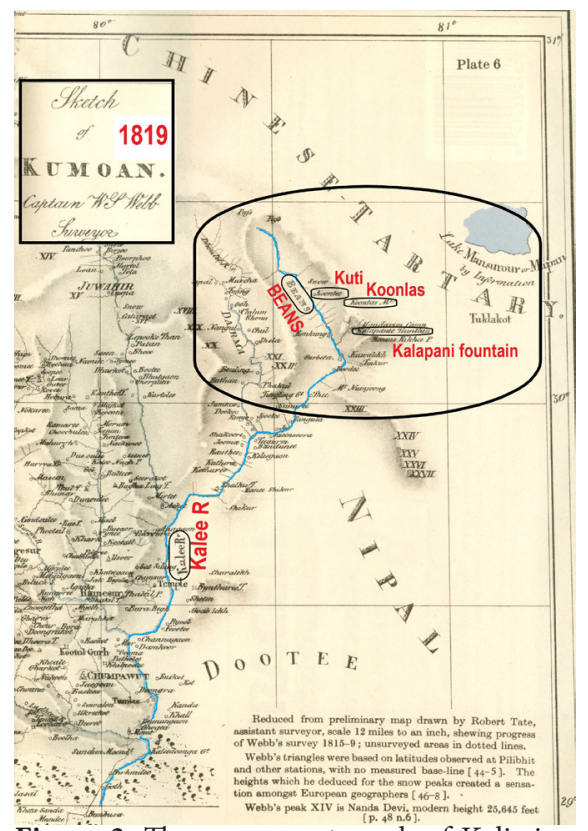

Figure 3: The uppermost reach of Kali river as the western borderline between BritishIndia and Nepal (https://pahar.in/indiansubcontinent-pre-1899)

The western border river 'Kali' (Article 5 of Sugauli treaty, 1816), is now called as Mahakali in Nepal and Sarada in India. The map of 1819 (Figure 3) had clearly demarcated the headstream course of Kali as "Kalee R" to the river mentioned by the Sugauli Treaty. The river name was given on the base of the traditional name and information provided by the local residents. The map of 1819 and other maps published 
in $1827,1834,1835,18371846,1848,1850$ and 1856 had marked the Kali to the river coming from Limpiadhura which had followed the main river principle as well. In addition, another supporting document to the maps was the letter of John Adams as described in the subsequent chapters.

\section{Data and methodology}

The paper is prepared on the basis of historical facts, published documents, correspondences and several maps since 1815 (Bhandari, 2015; Baral, 2007, Shrestha, 2003; Manandhar, 1996). Relevant papers and articles published in the peerreviewed journals (Manandhar \& Koirala, 2001; Dhungel \& Pun, 2014), periodicals and newspapers (Bhusal, 1996) are also reviewed. Reviewed documents also include treaties and books as well. Copies of authentic maps from 1816 onwards, the political boundary map published by the Survey of India and the administrative boundary of Nepal published by the Survey Department of Nepal were analyzed. Cartography includes the map making process and a map not properly designed is called the cartographic failure (Robinson, 1953). Fictitious or fake entries on relevant historical maps are analytically interpreted. Interpretation of maps is also made with reference to the recent freely available Google maps (https://www.google.com/earth/versions/), which helped to clarify the confusion arising in interpreting large scale maps. Copies of original correspondences have been taken as authentic views of concerned authorities. In addition, the river science principle developed by John Playfair in 1802; R E Horton in 1945, AN Strahler in 1964 and Bhusal in 1996 (Bhusal, 1996; 1998) was also considered to define the source of the main river in question, i.e. Mahakali /Sarada/ Kalee river. Hydro-sub module of ARC GIS using 30 meter DEM (ASTER) (NASA, 2010) is used to map the uppermost watershed of the Kali river with GIS software and the same map so produced is used as a base map to locate the borderline shifts.

\section{Evolution of cartographic aggression by India}

Since the signing of the treaty in 1816 , several maps were published by the British East India Company and by the Government of India, some of them found showing the fictitious entry to the source of the Kali river. After India got independence, both Nepal and India signed a 'Peace and Friendship Treaty in 1950' which states that "The two governments agree mutually to acknowledge and respect the complete sovereignty, territorial integrity, and independence of each other" (Bhandari, 2015). This factually recognized the territorial integrity of two countries as set by the Sugauli Treaty of 1816. Though there had been the gradual shifting of borderline from 1 to 6 as shown in the Figure 4 by the cartographic aggression in the north-west border of Nepal, the local residents had noticed a few tent camps of Indian border security force on the left 
bank of Lipu stream at Kalapani at around 1952. Till 1961, India's motive seemed to hold Lipulek pass solely within the Indian territory (Surveyor General of India, 1961; Survey of India, 1960). The Nepal-China border agreement treaty of 1961 has marked No-1 pillar at the Tinker and Karnali watersheds. This had motivated India to push cartographically Nepal's border to a few kilometers south-east of Lipulek to the meeting point of watersheds of Karnali, Tinker and Lipu.

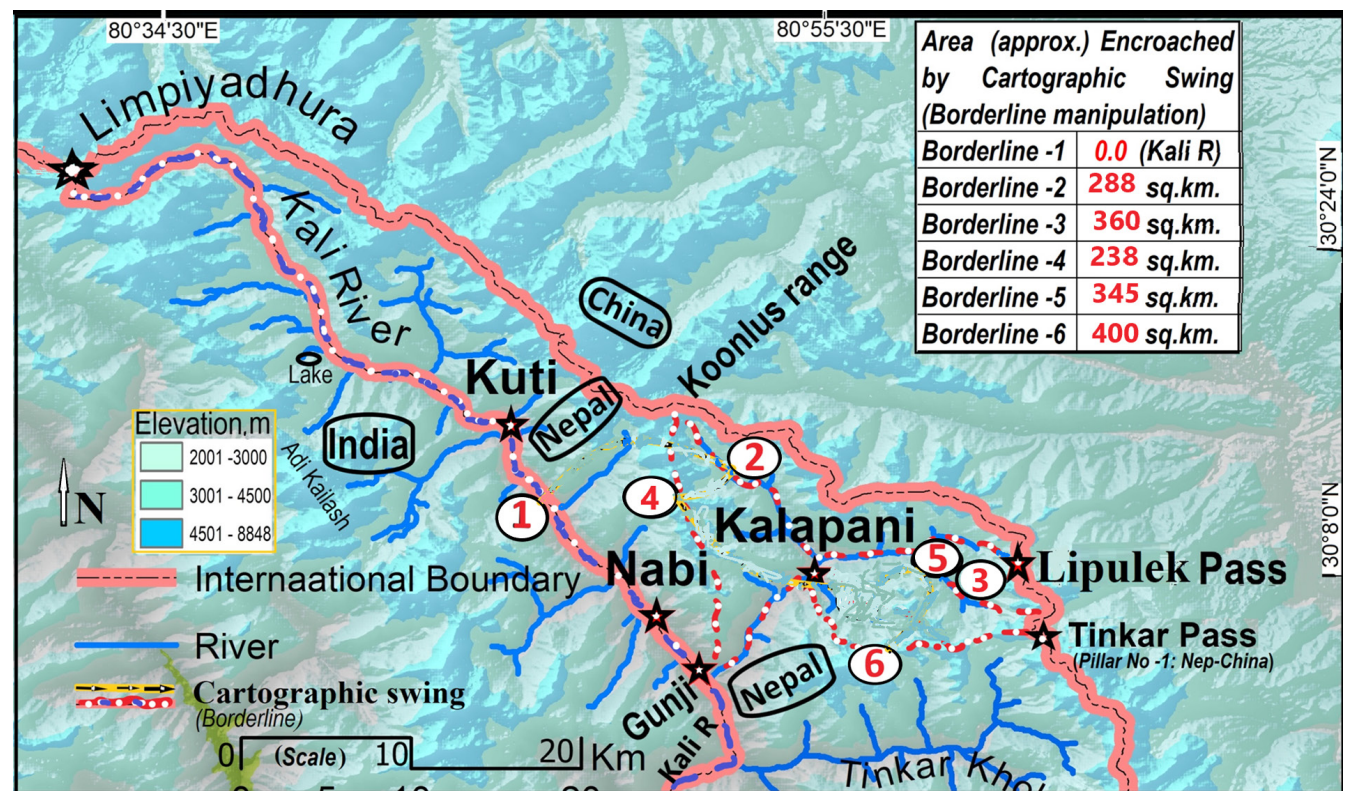

Figure 4: Map showing cartographic manipulations (Borderlines No 1 to No 6) and areas

\section{The inception of Cartographic Aggression}

After the Sugauli treaty, Bhootiya Zamindars (the community leaders) of villages in Byas Pargannah of Kumaon wanted to retain three villages namely, Gunji, Nabi and Kuti (Cox, 1824) within Kumaon of the British territory. But, Bum Shah, the Chautariya and officer responsible for the Doti district of Nepal, had sent an objection letter to the British regime claiming that those villages belonged to Nepal. In response, John Adams, the acting secretary, who had also served as acting Governor-General (Jan-Aug 1823) of British India had confirmed that those three villages lie eastwards of Kali river and so belong to Nepal. On 4 February 1817, he sent an order letter to GW Trail, the Commissioner of Kumaon to surrender those villages to the regime of Nepal with a copy letter of the same to Edward Gardner, the resident commissioner of British India in Kathmandu (Manandhar, 1996; Cox, 1824). But, it seemed that the Zamindars of Byas continued their efforts to persuade the company government which can be seen 
reflected on the map of 1819 prepared by Captain W.S. Webb, the officer, who was sent to Kumaon area for the barometric survey. Although, the map has shown the river Kalee without marking the river course as the boundary between the two countries (Figure 5). In addition, the manner in which the watershed areas of Lipu stream and Kalee/ Kali were drawn, clearly showed the fictitious (Monmonier, 1996) entry on the map to support to the Company and Zamindars' interests to include said watersheds under the territory of Kumaon region.

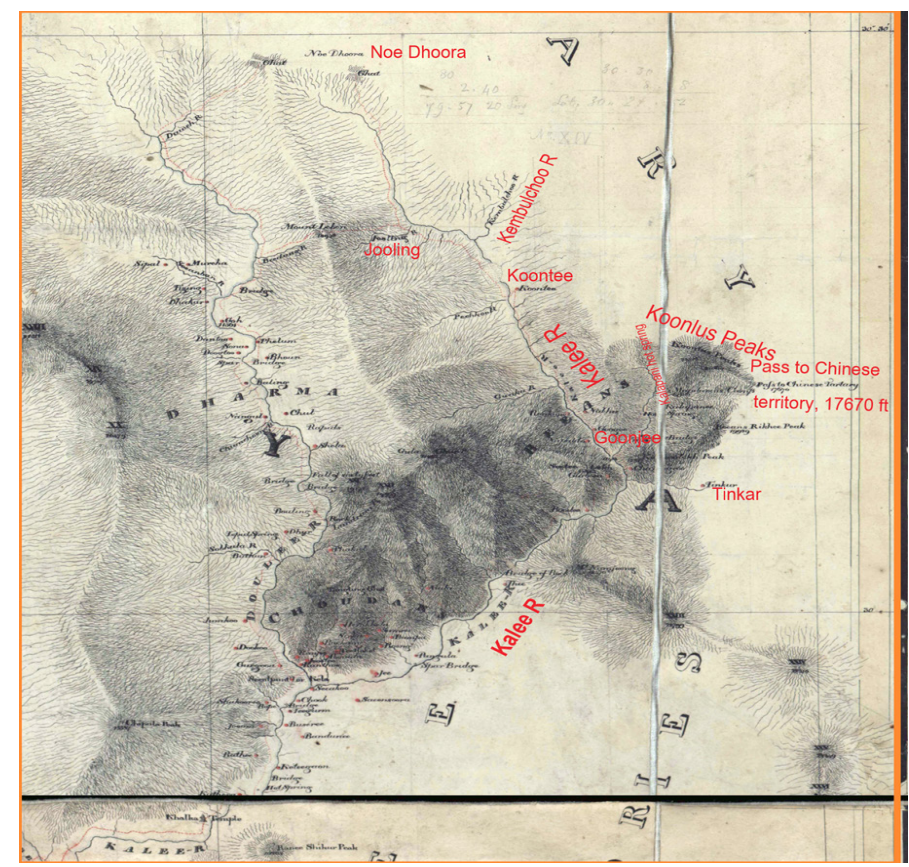

Figure 5: Map of Province of Kumaon by Webb, 1819 . (Kalee river is shown but borderline is not clearly marked.)

\section{Cartographic manipulation: Borderline 2}

From the maps published after 1819, one would see the gradual cartographic aggression to Nepal's territory. In the map of 1827 (SOI, 1827; Horsburgh, 1827) (Borderline-2, Figure 4) is marked by an unnamed stream originating from the Koonlus range (Figure 6), which was named as Tera Gadh in the map of 1879 (Figure 10). This river flows towards the south, confluences with the stream coming from the Lipulek Pass and then meets Kali at Gunji (Figure 6 and Figure 7). The International borderline was shifted from location 1 to location 2 (the course of Tara Gadh). This shifting encroached about 238 sq. km of Kali's upstream and about 50 sq. km of Lipu's watershed of Nepal. 


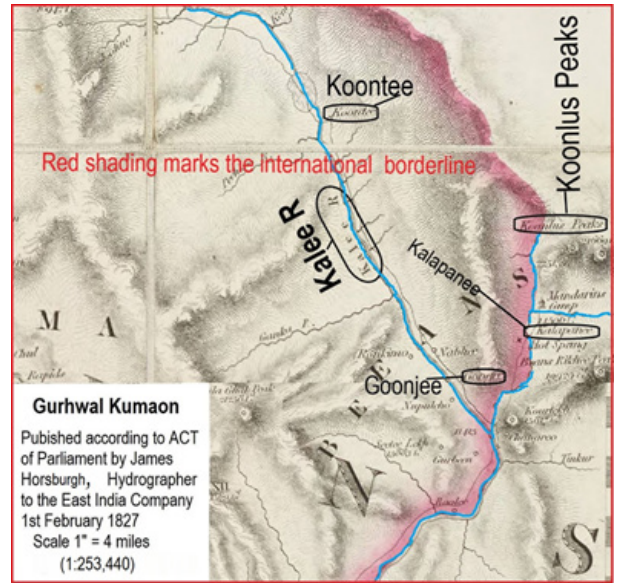

Figure 6: The international borderline is shown by red color shading; Kuti, Nabi and Gunji are encroached ((Source: Surveyed by Webb and published by James Horsburgh, East India Company, London, 1827.)

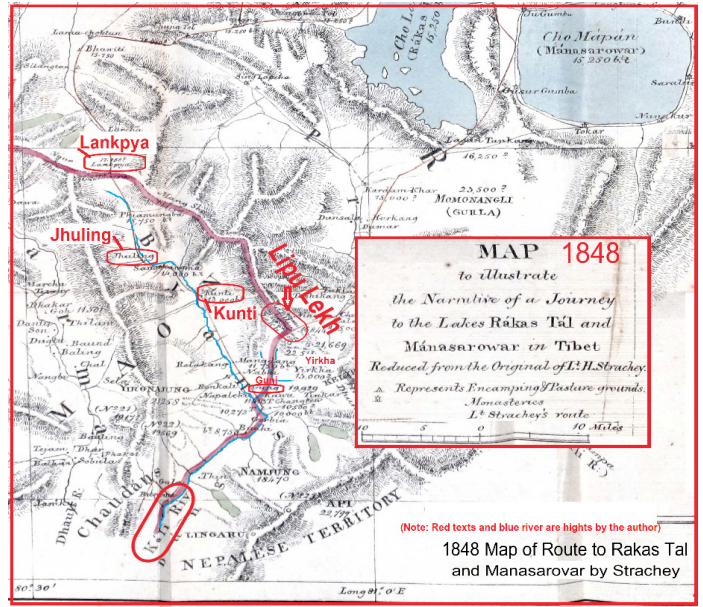

Figure 7: Paths to Mansarowar, Rakshes Tal and Mt. Kailash with manipulating Lipulek as the common border (Strachey, 1848).

British India seemed to be attracted to Kuti (3800 meters above mean sea level), Nabi and Gunji villages. Because they are the uppermost settlements that served as base camps for those wanting to cross to Tibet, routes to Adi (Chhota) Kailash and Parbati Kunda (Pond) and routes to Rakshes lake in Tibet as well. Further, continuous requests of Bhootiya Zamindar of Kumaon to retain those villages within the Kumaon jurisdiction would have been also an additional motivating factor for borderline manipulation. Whatsoever, the river science perspective postulated by John Playfair in 1802, R E Horton in 1945, AN Strahler in 1964 and further defined by Bhusal, 1996 does not support to name Tera Gadh stream as the uppermost reach of the main Kali river (Bhusal, 1996).

\section{Manipulation in the location of Lipulek}

In 1846, the East India Company sent Henry Strachey and Richard Strachey to the Kumaon region for undertaking the survey of the region including routes to Tibet in a scientific manner. In 1848, Henry Strachey (Strachey, 1848) published a route map (Figure 7) without naming Kalee/Kali as in the earlier maps. He had used the 1827 and 1842 maps by Arrowsmith as the base map which had marked the borderline along the Tera Gadh stream coming from Koonlus peak. Strachey named the location of Lipulek pass to about 11 kilometers east on a phantom location on the Koonlus range, the source of Tera Gadh river. In addition, he also fabricated that river flowing from Lankypa dhura to name as Kalee/Kali would not be in the interest of the British East India Company. 


\section{Cartographic manipulation: Borderline 3}

British India became more aware of the importance of Lipulek pass, as it is crossable to Tibet for purposes, like trade and transit, trek to pilgrim to Mt. Kailash and Mansarowar in all seasons except the extreme snowfall days. The British rulers were aware of the report of Strachey brothers who surveyed the area during 1846-48 and published papers, which had indicated the importance of Lipulek pass. The map prepared in 1848 importantly put legend of paths to Mansarowar lake, Rakshas lakes, and Mt. Kailash.

The map of Kumaon and British Gurwal (Figure 8) was published in 1850 by the East India Company (Surveyor General of India, 1850). This map located (brought back) the Lipulek near to its real position and the borderline (Borderline 3, Figure 4) was drawn along the stream but without naming it as Lipu stream by including the Lipulek pass within the British territory. This map changed the borderline from Tera Gadh river to the river coming from Lipulek range. This is what Strachey brothers had visualized. Because, of the different passes in the range, Lipu is the most accessible pass to Tibet in all seasons except during extreme weather. So very tactfully Lipulek pass was included under the British Territory. Interestingly, this map did not provide the name to the river flowing from Limpiadhura.

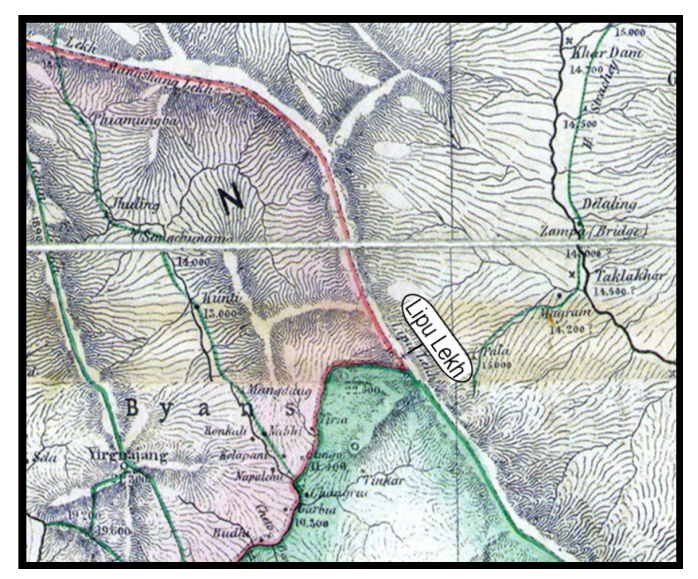

Figure 8: The black bold line along with red line is marked as borderline which after Gunji follow Tiria (Tera Gadh) and Lipu stream (Surveyor General of India , 1850).

\section{Manipulation in the river names}

After noting the Lipulek pass to be a strategic location, British India got attracted to taking control over the Lipulek pass of Nepal by legalization through cartographic conspiracy around the 1850s. The British rulers' intention to encroach Lipulek pass 
by means of cartographic aggression, was fueled due to less technical knowledge on Nepal's side and due to less frequent surveillances/visits to that area by Nepalese authorities due to the remoteness. But during 1856-57, there was an uprising against the British rule in Calcutta, Lucknow and other places in India (Thapa, 2013; KC, 2004 and Bhandari, 2015). With the support of the Nepali soldiers led by Janga Bahadur Rana, the East India company government succeeded in suppressing the Lucknow uprising. As a mark of gratitude, the British Company government did not only adopt a policy of friendship but also returned the four districts Banke, Bardiya, Kailali and Kanchanpur, known as "Naya Muluk" to Nepal in 1860, the plain area between Kali to the west of Rapti taken by the company government in 1816 (Regmi, 1958). However, the British India waited for an opportune time to detach the Lipulek from Nepal. All maps prepared and published earlier including the map of 1856 (Figure 9) had been demarcating the Kali up to its the source at Limpiadhura snowy mountain range (British Survey of India, 1856). In all maps, Kali originates from Limpiadhura, flows to south-east direction up to Gunji and then flows towards the southerly direction. A tributary stream coming from the Lipulek side joins the Kali river at Gunji village.

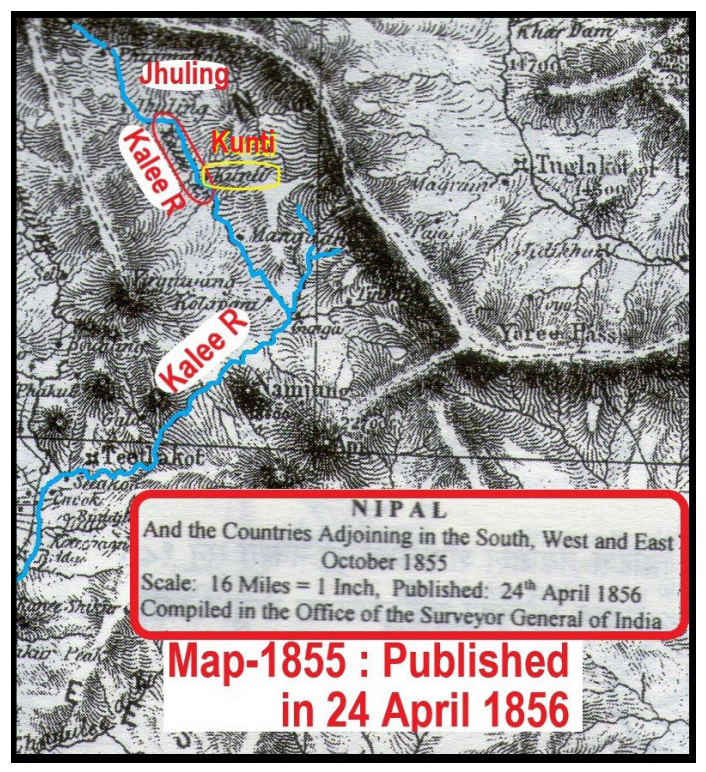

Figure 9: The river originating from Limpiadhura is marked as "Kalee R" and Kuti is located on its left bank,

The cartographic manipulation (Figure 4, Borderline-2) in encroaching Gunji, Nabi and Kuti area, had ignored the Kalee river course and the river science principle in defining the head stream of main Kalee. And, Lipulek Pass was left under the Nepalese jurisdiction while considering the course of Tera Gadh as the Nepal-British-India borderline. 
Similarly, the cartographic aggression over Lipulek (Figure 5, Borderline-3) presumably following the Lipu Stream course as borderline had also ignored the traditional Kali river and the river science principle in defining the main river. Therefore, British-India applied conspiracy towards river names. Almost all the maps published before 1865 had clearly indicated Limpiadhura as the source of the Kalee/Kali River (Figure 9). The map published then after by the Surveyor General of India during 1865-77 changed the name of Kalee/Kali river to Kuti Yangdi, which was suggested by Henry Strachey in his paper/report. And the river flowing from west of Lipulek was named Kha-Yangti (Bhandari, 2015). The map of titled 'Nepal, Almora district, United Province' published by the Surveyor General of India in 1879 (Figure 10) gave the name 'Kuti Yangti' to the traditional 'Kali' river flowing/originating from Limpiadhura and the name 'Kali' was given to the Lipu Khola (stream) flowing from Lipu range. With regard to the boundary with Nepal, the map neither follows the Kalee/Kali river called as Kuti Yangdi nor follows the Lipu Khola fictitiously called as Kali. Rather, a small spout-spring located at about 30 meters southwest of Kalapani on the left bank of Lipu river is shown to be the source of the Kalee/Kali river, which is a kind of phantom attempt in legalizing the borderline shift.

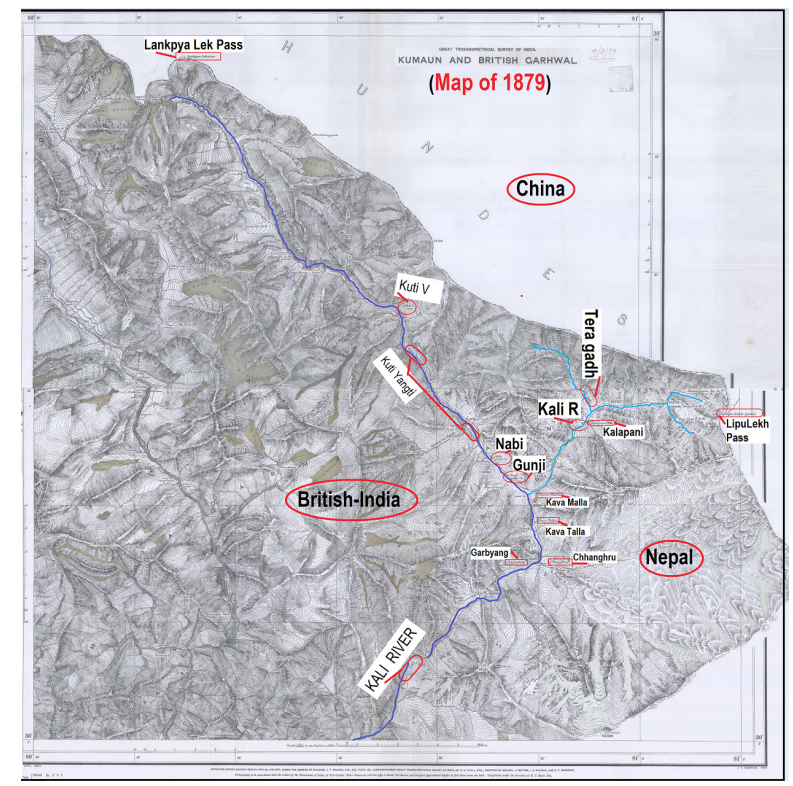

Figure 10: The river originating from Limpiadhura is marked as "Kuti Yangti" and "Kali" to river from Lipulek

\section{Cartographic manipulation: Borderline 4}

The belief of the Hindu that the 'River Ganga' originated from the 'Shiva's head' is the pictorial interpretation that the main river comes from the top of the mountain on the 
farthest point. More than that, the main river at any confluence is distinguished from its length, its water volume, its watershed area and the number of tributaries to it (Playfair, 1802; Horton, 1945; Strahler, 1964 in Bhusal, 1998). At the Gunji confluence, the uppermost reach of Kali, (named as Kuti Yangti/Yangdi) is about three times larger in the average water flows, about two and half times longer in the main channel's length, three times larger in the watershed area, and has a greater number of stream orders. Noting the river science principle, later around the $1880 \mathrm{~s}$, British India had realized that a small stream either originating from Koonlus range or Lipulek range cannot be the uppermost reach of the main Kali river. Therefore, another manipulation was created by the false interpretation in naming the border river reaches of Kali only up to the Gunji confluence, and to the north from Gunji confluence, the watershed divide lines were marked to be borderline. A map titled 'Tibet-Nepal-United province' published by the Surveyor General of India in 1881 showed three different shedding - one for India including the Kuti area, another for Nepal including Lipu area and the third one for Tibet (Figure 11). The map of 1881 and several maps printed onwards had been following the same explanation (Figure $12 \mathrm{a}, \mathrm{b}, \mathrm{c}$ ). It was done to mark the Kali as the border river up to the Gunji confluence and north from Gunji, the watershed divide line as the borderline (Figure 4, Borderline-4). The explanation by 'The Gazette of Almora' in 1911 had also justified this aggression by stating: "The Kali on the east has its true source in the Kuti Yankti which after the in fall of the Kalapani river takes the name of Kali" (UP State Archives, 1911). The map published as 'The United Provinces (1907-09)' (Imperial Gazetteer of India, 1909) is also found colored accordingly which encroaches about 238 sq. $\mathrm{km}$ of Nepalese territory while the whole watershed of Lipu (Kalapani) was shown within Nepal. Such phantom interpretation prevailed up to around the 1920s until when maps of 1928-29 published which indicated the Indo-Nepal borderline as appeared in the 1879 map (Figure 10).

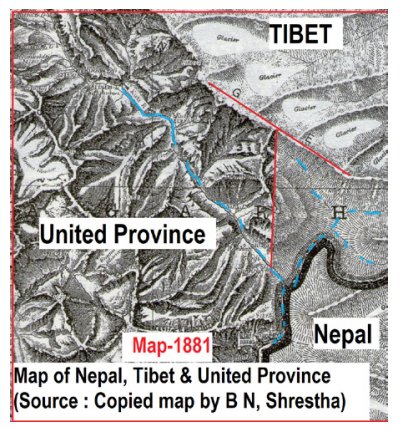

Figure 11: Map of Nepal, Tibet and United Province (1881).

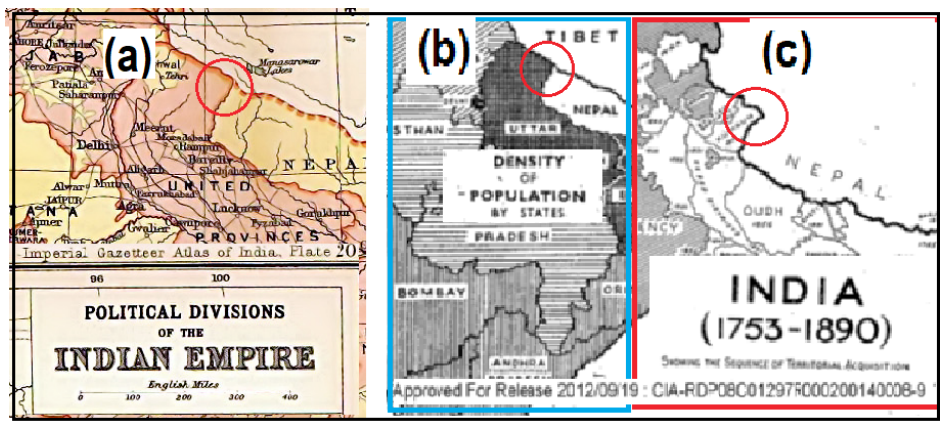

Figure 12a: Political divisions of the Indian Empire, Imperial Gazetteer of India: Atlas 26, Oxford (1909). Figure 12b \& Figure 12c Old map released by CIA on 2012/09/19 
The map published in 1946 by the National Geographic Society of USA indicated the borderline towards Limpiadhura (Figure 13a), which almost coincides with the map dated 14 August 1947, when Pakistan was declared an independent state while ending the British rule over India. The map published by the CIA, America also showed borderline towards Limpiadhura (CIA, 1947). But the political map of India also dated 1947 (Figure $13 \mathrm{~b}$ ) created confusion to mappers by demarcating the international borderline between Nepal and India as shown in the Map of 1928/29. It may be noted that independent India in around 1950s seemed considering the international borderline up to the confluences of the stream (Tera Gadh) originating from Koonlus range and the stream (Lipu Khola) originating from Lipulek range, and then onwards the borderline was demarcated either following watershed divide lines of Lipu stream or along the course of a very small tributary stream towards the southerly direction to about 8 kilometers and then towards east direction up to the point joining the Tinkar watershed and Karnali watershed. Due to the smaller scale, the map published in 1961 (Figure 14) may either be interpreted.

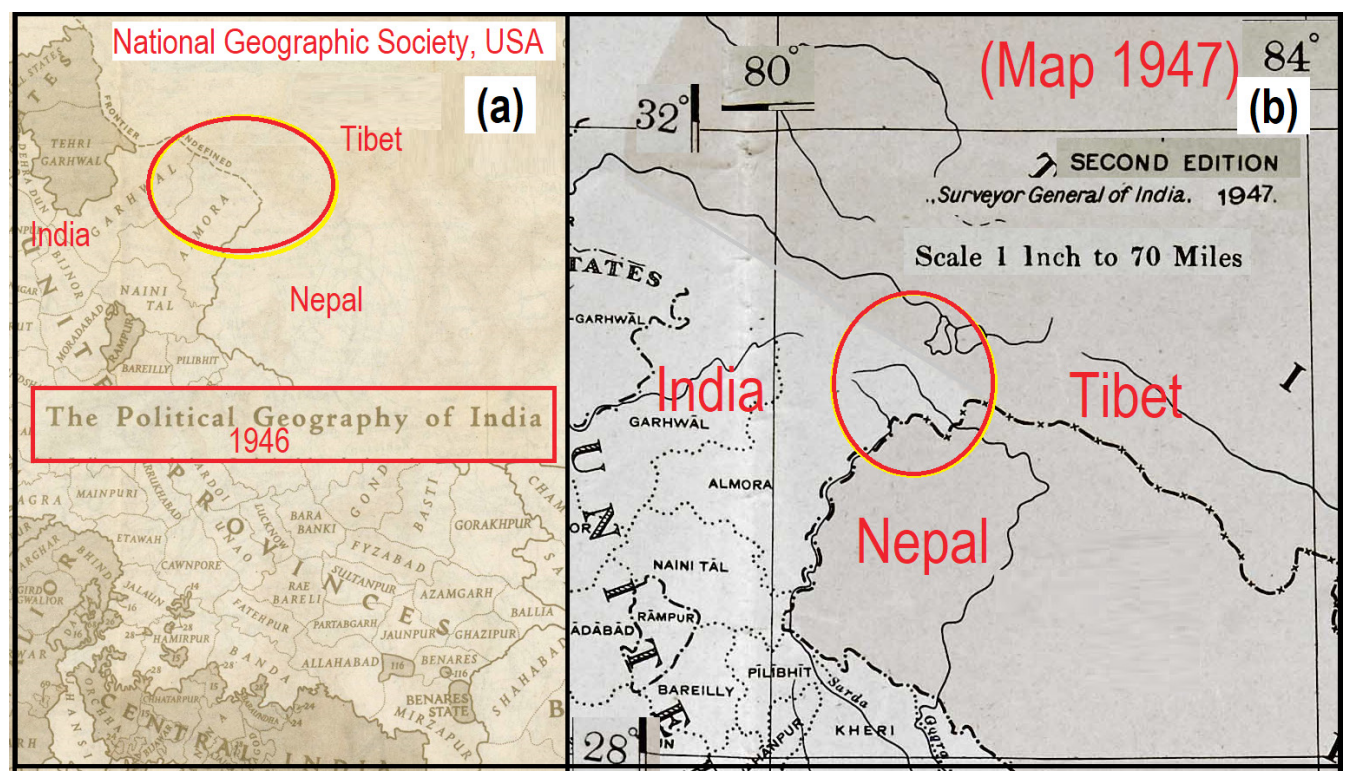

Figure 13 a: Political Geography of India (1946). NGS, USA; Figure 13b; Political map of India (1947). Map-11 (ii) (1947) 


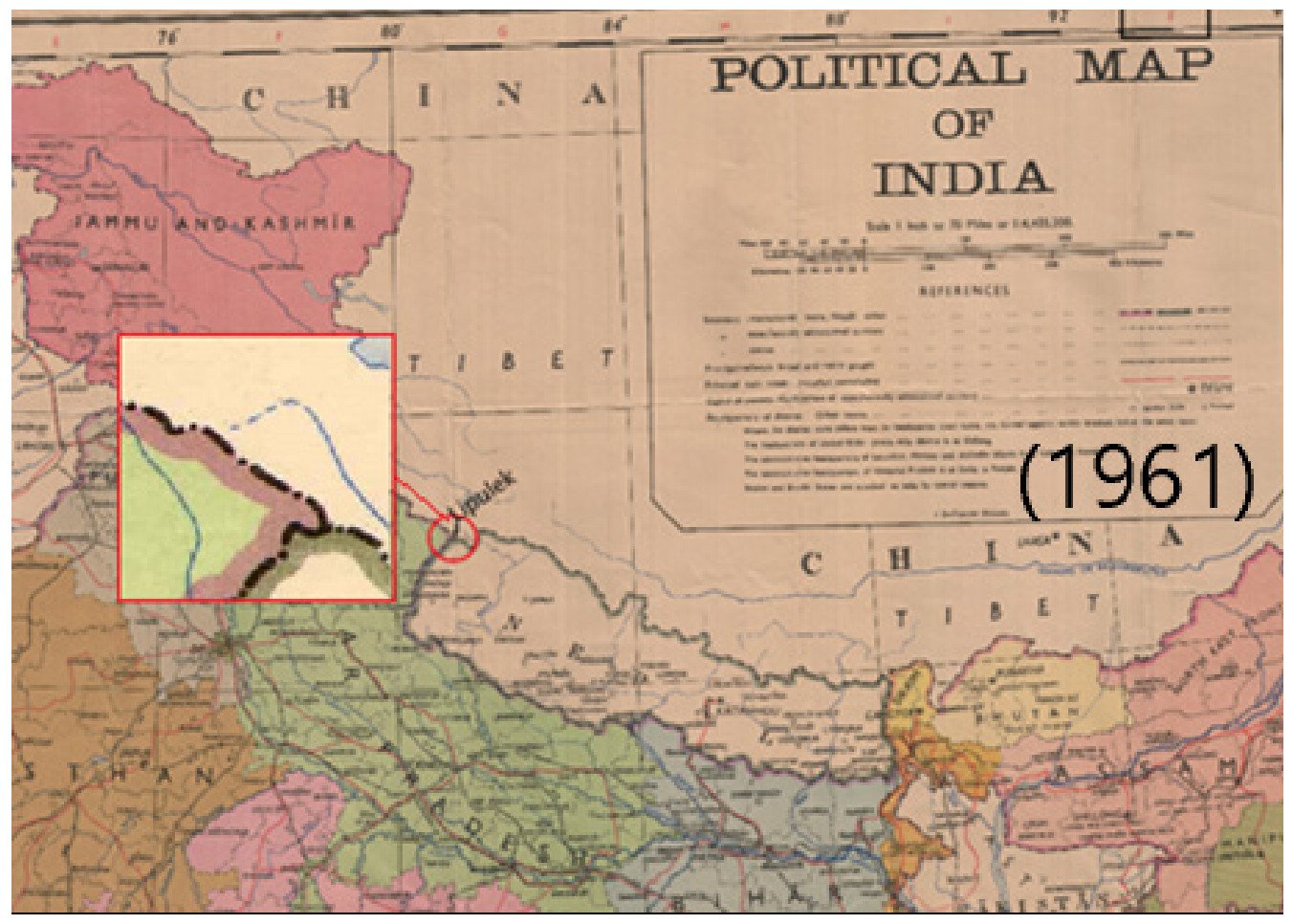

Figure 14: The Political map of India, $6^{\text {th }}$ edition, 1961 (Survey of India).

\section{Cartographic manipulation: Borderline-5}

The mapping technology in Nepal was far behind during the 1950s and Nepal lacked skilled cartographers. Nepal had not its own political map before the 1970s and has her map published in 1975. Nepal had been using maps prepared by the Surveyor General of India. Therefore, the map used by Nepal as the reference map during the border agreement between Nepal-China in 1961 was the Indian map which had fictitiously named as 'Kali' to the Lipu steam. This resulted in a further error from the Nepalese side (Figure 4, Borderline-5) even though Lipulek and Kalapani are shown within Nepal. Nepal blindly believed in the Indian maps that had named the Kali river to the Lipu stream (Figure 15) which also created the illusion on the international border and the tri-country border point of China, Nepal and India. In fact, the tri-country border should fall at Limpiadhura peak which lies about $53 \mathrm{~km}$ west from Lipulek as per the Sugauli treaty. 


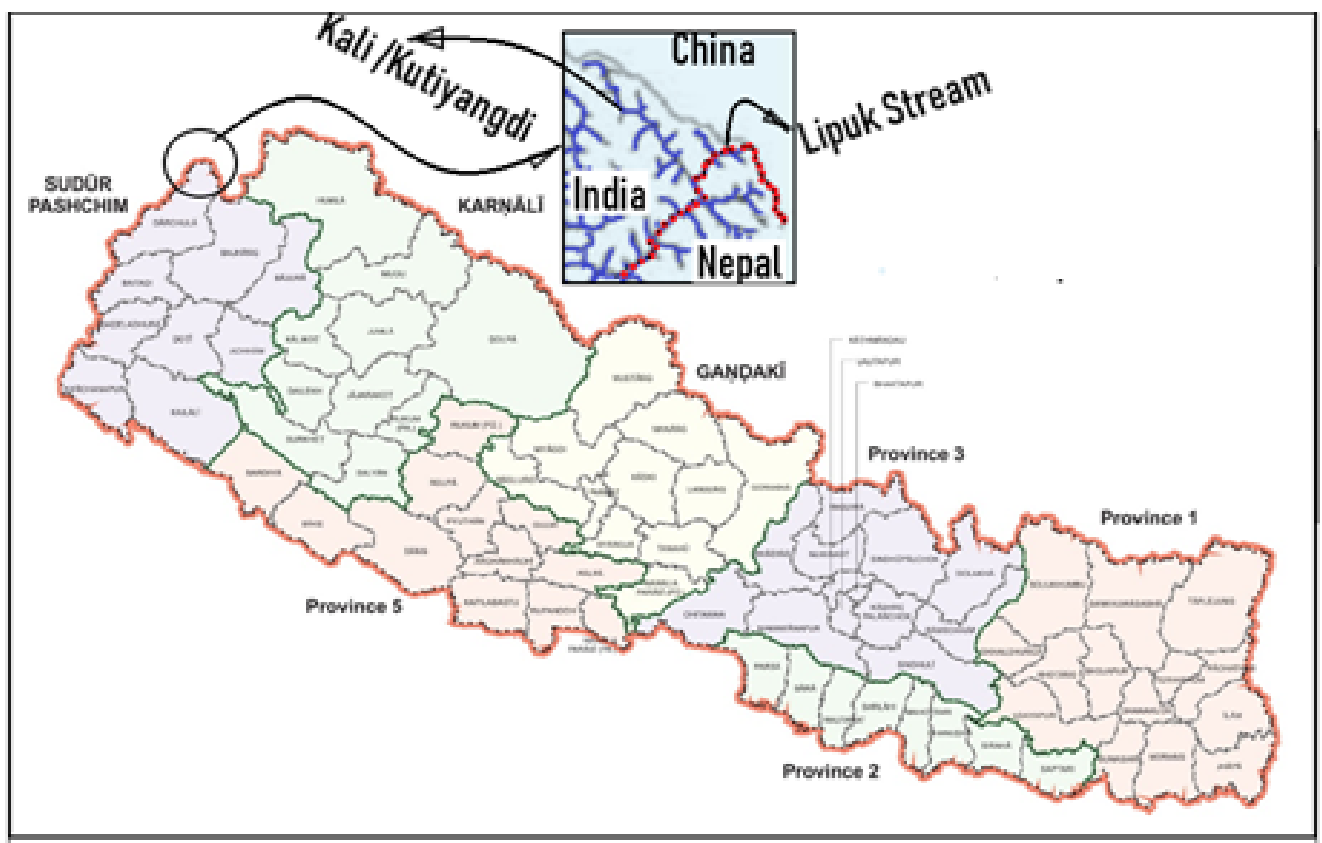

Figure 15: Administrative Map of Nepal (Source : Survey department of Nepal, 2019)

\section{Cartographic manipulation: Borderline-6}

It is said that India after being defeated in the war with China in 1962, strengthened her aggression over the north-west territory of Nepal (Figure 4, Borderline-6) further occupying almost 70 percent watershed area of Lipu stream, including Kalapani of Nepal (Figure 16i, 16ii). Added motivating factor was the flat land of about 17 hectares of Kalapani (3700 meter amsl) situated on the left bank (i.e. eastern bank) of Lipu stream, lying at 10 kilometers west of Lipulek pass to which India needed to camp her border security forces/troops to watch any activities from Tibet (China). To justify the encroachment, a spring spout on the left bank of Lipu stream at Kalapani, was again stressed to be the source of Kali and a temple of Goddess Kali was also built to show as an added proof as in the map of 1879, 1928-29 which were prepared unilaterally by the British-India. India has been insisting on the borderline of Kali river course up to the artificial source (Kalapani Spring and Kali temple) and therefrom, the borderline is marked along the watershed divide line to the south up to the point where Tinker watershed meets, and then to the east up to the point where Tinkar, Lipu and Karnali watersheds join (Imperial Gazetteer of India, 1931). 
The underlying motive to include Lipulek pass as a trading point in the joint statement issued at the end of the visit of the Indian Prime Minister Narendra Damodardas Modi to Beijing in 2015 was also further attempt to encroach the Lipulek pass permanently (MoEA, Government of India, 2015). It may be mentioned that Nathu La (about 4200 meter amsl) in Sikkim lies about $800 \mathrm{~km}$ to the east of Lipulek pass and Shipki La (about 3200 meter amsl) lies at $280 \mathrm{~km}$ to the west of Lipulek pass. Thus, Lipulek pass (about 5100 meter amsl) is the nearest point from New Delhi to Hindu heartland of lake Mansarowar and Mt Kailash for pilgrimage purposes and more on as trading route. Further, in spite of Nepal's claim of her territory, the Kali river course and all lands to the east of Kali, India published her political map on 2 Nov 2019 (8th edition) and 8th Nov 2019 (9th edition) (Figure 16i) unilaterally by encroaching about 400 sq. km of Nepal territory (Survey of India, 2019).

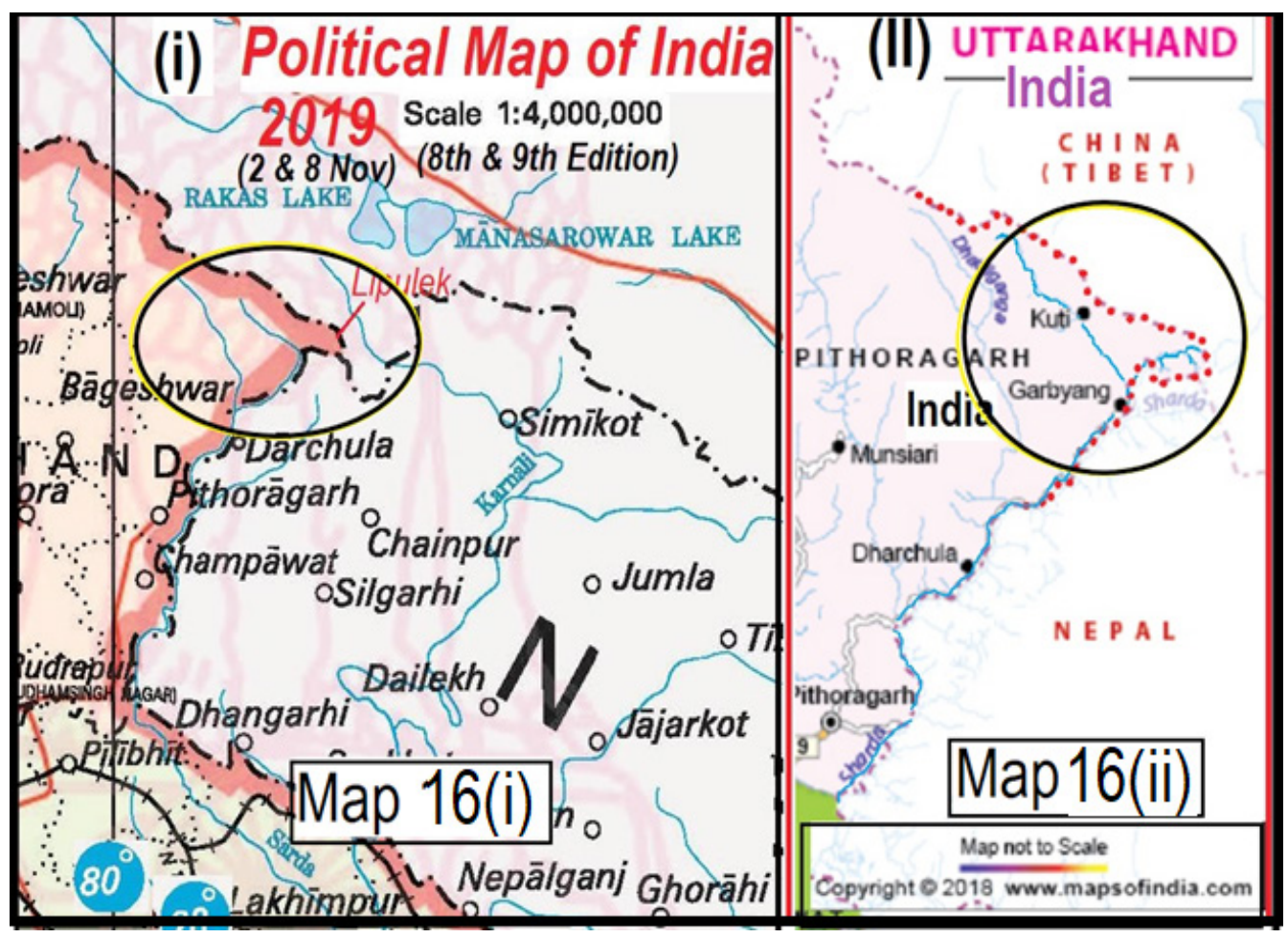

Figure 16 (i): The Political map of India, $8^{\text {th }} \& 9^{\text {th }}$ edition, 2019; Figure 16(ii): Map of Uttarakhanda (Survey of India). 


\section{Ground reality of the territorial dispute}

Unilateral manipulations of the North-Western borderline in the Indian maps, the oneafter-the another, were seen since 1827. However, Nepal had never left her claim of her territory to the east of Kali since 1816. Aged locals over that region reported that a few tent camps of the Indian border security force were seen at Kalapani in around 1952 (Aitawal, 1960; Regmi \& Khatri, 1973; Bohora, 2011; Bhandari, 2015). Since 1962, after the defeat in the Indo-China war, India had been extending its army camp and bunkers at both banks of Lipukhola/Tera Gadh stream despite the continuous objection from Nepal. Bhairab Risal, a 93 years old senior journalist of Nepal, is a living officer in charge of the census of 1961 of that area who had included all settlements situated on the east of Kali including the three villages of Kuti, Nabi, and Gunji (Risal, 2015). Old records of land ownership right in Kuti, Nabi and Gunji villages are available in the Land Administration Office of Doti district of Nepal which proves that the area up to Limpiadhura belongs to Nepal. Similarly, Bahadursing Aitwal (1960), Madan Bhandari (1990), Prem Singh Dhami (1993) (Lumsali, 1997) had made against the Indian encroachment of Limpiadhura-Lipulek a national issue. The reports of Puruswotam Regmi and Hari Prasad Khatri of 1973 (Regmi \& Khatri, 1973), report of Dwarika Dhungel of 1981, the letters of 1998 to the UN by the concerned citizens including Hiranya Lal Shrestha, and many others have been continuously opposing Indian encroachment of the said areas (Bhandari, 2015). It should be universally noted that unless the sovereign authorities/parliaments of both nations have approved the new border treaty, unilateral cartographic encroachments cannot overwrite the borderline delineated by the Sugauli Treaty of 1816 .

\section{Discussions}

Can it be questioned that India would be blocked completely to transit routes to Tibet in the future without a route through the Lipulek pass? Is India feeling unsafe from China even today, so that it needs the Indian army at the bunker on the occupied and encroached land of Nepal? Is India not familiar with war technology that has been moving further towards the GPS guided missile? And further, does not India want to be friendly with its neighbors in behavior in the real sense of the term? India must find answers to these questions by herself if she wants to be a nation that changes with the demand of time and technology and wants to play a role in the global arena.

Nepali people, in general, have been feeling bitter about the implementation of the water resources treaties signed with India. Therefore, if it (India) respects moral values, if it intends to be a rising power and a nation in competition with countries like China, Japan and US in technology and economy and, more importantly, wants to be a good neighbor, 
it is the right time for India to withdraw its army camp from the Nepali territory, east of Limpiadhura to Kalapani-Lipulek and respect the Nepali sovereignty to these areas.

The international boundary treaties overwhelmingly follow the fixed boundary principle. A treaty on fixed boundary principle was also agreed between Nepal and East India Company on 16 January 1845. It was signed between Mathbarsing Thapa, the Prime Minister of Nepal and Henry Montgomori Larence, the resident representative of EastIndia Company in Kathmandu (Bhandari, 2015). Unless and until, there is any other border treaty signed between two respective highest government authorities that define Kalapani as the ending point of borderline by river courses (i.e. Kali river), any attempts in cartographic manipulation do not hold any legal validity in the case of North-West borderline of Nepal. Furthermore, if Nepal continues to keep some of her territorial areas outside in its official map, India will get excuses to keep on illegally occupying and encroaching her lands in the days to come also. So, Nepal must withdraw her defective map and release the correct map with a white paper note on the basis of the provisions of the Sugauli Treaty. In addition, Nepal must show its vivid presence/appearances in the area by undertaking development activities focusing on local livelihoods, high altitude tourism facilities with access road and electricity. In addition, continuous moral pressure, be put on India to leave encroached areas, not only in the east of the Kali river but also in Susta and other locations.

\section{Conclusions}

The letter of Lord Hastings, the Governor General of British India to the secret committee had recommended in colonizing Kumaon and Gurwal for getting easy access to Western Tibet for trade. But the borderline by Kali river by Sugauli treaty 1816 left Kuti, Lipu and Tinker pass within Nepal. In 1817, in response to the petition by local Bhootiya Zamindar to East India Company through Commissioner of Kumaon requesting to hold Kuti, Nabi and Gunji villages under the British regime, acting chief secretary as authorized by the Governor-General of British India Company had made clear that villages in question belong to Gorkha (Nepal) regime.

When Strachey brothers found the Lipulek pass the easiest and short route to the places of pilgrimage and for trading in Western Tibet, the British regime craved over the Lipulek Pass. The intention of British to encroach a swap of land from Limpiadhura to Lipulek pass by means of cartographic aggression, not by the war, was fueled partly because of less technical mapping knowledge on Nepal's side and of less frequent surveillances/ visits to that area by Nepalese authorities due to the remoteness. 
India, after the defeat of the Indo-China war, has been considering Kalapani and Lipulek as the strategic locations to watch any security threats to India and so had been further strengthening the occupation. Lack of awareness, capacity and political instability is Nepal's diminutive role in defending her territorial integrity set by the Sugauli treaty. In general, international boundary treaties overwhelmingly, adopt the fixed boundary principle. Nepal and East-India company had the fixed boundary principle treaty also signed on 16 January 1845. Still more, Nepal had never left the claim of her territory to the east of Kali since 1816. Therefore, the unilateral cartographic manipulations on the North-Western borderline in the Indian maps, one after the other since 1827, are against the spirit of the Sugauli treaty 1816.

Lipulek pass is the relatively easiest path to the Hindu heartland of lake Mansarowar and Mt Kailash for pilgrimage tourism, an emerging trading route and still a strategic location for border security to India. Mention of the Lipulek pass as a trade route in the Joint Statement between India and China during Prime Minister Modi's visit to China in 2015 and inclusion of Limpiadhura-Kalapani-Lipulek in the political map of Indian in 2019 challenges to Nepal as well as also an opportunity for Nepal to sort out the border issue with India. Putting continuous moral pressure diplomatically over India would be the vital tool to get back all encroached areas, not only in the east of the Kali river but also in Susta and other locations.

\section{Acknowledgments:}

The author would like to thank Dr. Dwarika Nath Dungel for his valuable inputs and suggestions including language correction who has inspired me to publish the paper.

\section{References}

Acharya, B. (2013). The bloodstained throne: Struggles for power in Nepal (17751914). UK: Penguin. doi:ISBN 978-93-5118-204-7.

Aitawal, B. S. (1860). Objection letter to the commisioner of Kumaon. In R. Bhandari, Atikraman ko chapetama Limpiyadhura-Lipulekh, 2015 (p. 96). Kathmandu: Ratan Bhandari.

Ali, J. R., \& Aitchison, J. C. (2005). Greater India. Earth-Science Reviews, 72 (3-4), 170-173. doi:10.1016/j.earscirev.2005.07.005.

Baral, K. (2007). Mahakali border dispute and the true Kali river. Unpublished Master's Thesis, Tribhubhan University, Central Department of Geography, Kirtipur, Kathmandu.

Bhandari, R. (2015). Atikraman ko chapetama Limpiyadhura-Lipulekh (in Nepali). Kathmandu: Ratan Bhandari. ISBN:978-9937-2-9665-6. 
Jagat K. Bhusal / Evolution of cartographic aggression by India: A study of... Vol. 13: 47-68, 2020

Bhusal J. K., (2005), Kali (Mahakali) River and Kalapani area. Baigyanikjagat, (Ashad, 2062). Ministry of Science and Technology, Kathmandu, Nepal. (Nepali language). Year 4, Number 4.

Bhusal J. K., (1996)m The origin of Mahakali River, Kantipur daily, November 3, 1996 ( in Nepali).

Bhusal, J. K. (1998, September 6). Mahakali, a hydrological perspective. The Kathmandu Post, English daily.

Bohora, G. S. (2011). Raithanka Dristima Kalapani (in Nepali). Kantipur Daily.

British Survey of India. (1856, April 24). Nipal and the countries adjoining in the South, West and East, (October 1855). Survey of India.

CIA. (1947, August 15). The Indian Union and Pakistan. CIARDP08C01297R000200140008-9.

Cox, J. L. (1824). Papers regarding the administration of the Marquis Hastings in India. London: India office Library.

Dhungel, D. N., \& Pun, S. B. (2014). Nepal-India relationss:Territorial/Border issues with specific reference to Mahakali River. FPRC Journal ( A quarterly research journal devoted to studies on Indian Foreign Policy, Foreign Policy Research Center, New Delhi, ISSN 2277-2464.

Dungel, D. N. (1981). A field report on Kalapani encroachment submitted to the ministry of home (A visit made during 20 July to 11 Aug 1981). In book, Atikraman ko chapetama Limpiyadhura-Lipulekh, (p. 213-216)by Bhandari (2015). Kathmandu: Ratan Bhandari.

Dhungel, D. N. (1981). A Field report on Kalapani encroachment submitted to the ministry of home (A visit made during 20 July to 11 Aug 1981). Kathmandu.

Dungel, D. N. (1999, September 18). A field Inspection of Kalapani as a Chief District Officer. Jana Astha weekly. Kathmandu, Nepal.

Gurung, S. B. (2019). Save the Border Campaign, Nepal. Map of Nepal. Mapping Committee of the Save the Border Campaign, Nepal.

Imperial Gazetteer of India. (1909). Atlas, Vol 26, Oxford (1909). Great Britan: Oxford : Clarendon Press, Digital South Asia Library. Retrieved from Imperial Gazetteer of India: Atlas, Vol 26, Oxford (1909),: https://www.worldcat.org/title/imperialgazetteer-of-india/oclc/48172249.

Imperial Gazetteer of India. (1931). Nepal and Part of Tibet. Atlas , 26, 1931, 45. Imperial Gazetteer of India.

Imperial Gazetteer of India. (1931). The United Provinces. Atlas, 26, 1931, 33. Imperial Gazetteer of India.

JWG. (1998, July 17). Minutes of the fifth meeting of the Joint Working Group on the Indo-Nepal Boundary. In book, Atikraman ko chapetama LimpiyadhuraLipulekh, (p. 332-334)by Bhandari (2015). Kathmandu: Ratan Bhandari. 
Jagat K. Bhusal / Evolution of cartographic aggression by India: A study of... Vol. 13: 47-68, 2020

Lumsali, R. R. (1997). MAHAKALI NADIBAT PRAPTA UPALABDHIKO RAKSHA GARDAI THAP UPLABDHIKOLAGI SANGARSHA GARAU. Kathmadu: Rishi Raj Lumsali.

Manandhar, M. S., \& Koirala, H. L. (2001). Nepal-India boundary issue: River Kali as international Boundary. Tribhuvan University Journal, 23(1), 1-21.

Manandhar, S. B. (1996). Copies of Historical Document on Border issues related to Kalapani and Mechi.In book, Atikraman ko chapetama Limpiyadhura-Lipulekh, (p. 191-207)by Bhandari (2015). Kathmandu: Ratan Bhandari.

Manandhar, T. (1983). Some Aspects of Rana Rule in Nepal. Kathmandu: Purna Devi Manandhar.

MoEA, Gov. of India. (2015, May 15). Joint Statement between India and China during Prime Minister's visit to China in 2015. Prime Minister's Media Statement in Beijing during his visit to China. Retrieved from https://mea.gov.in/SpeechesStatements.htm?dt1/25239/prime+ministers + media + statement + in + beijing + dur ing+his+visit+to+china + may $+15+2015$.

Monmonier, M. (1996). How to Lie with Maps. Chicago: University of Chicago Press. doi:ISBN 0-226-53421-9.

NASA. (2010, May 14). Advanced Spaceborne Thermal Emission and Reflection Radiometer (ASTER) 30-Meter-Resolution Digital Elevation Model (DEM). Retrieved from National Aeronautics and Space Administration's (NASA) Earth Observing System (EOS): https://www.nasa.gov.

Paudyal, G. (2013). Border Dispute between Nepal and India. Researcher: A Research Journal of Culture and Society, 1(2), 35-48. doi:v1i2.9884.

Rajan, K. V. (2000, June 12). India will withdraw from Kalapani if it is proved to be in Nepal. (R. o. Kantipur, Interviewer) Kathmandu: Daily, Kantipur.

Regmi, D. R. (1958). A century of family autocracy in Nepal: being the account of the condition and history of Nepal during the last hundred years of Rana autocracy, 1846-1949. Kathmandu: Nepali National Congress.

Regmi, P., \& Khatri, H. P. (1973). A Report on the Encroachment of Kalapani - 2030 ( 16 September to 2 November 1973) submitted to the Minister of Foreign Affair, GoN. Kathmandu:In book, Atikraman ko chapetama LimpiyadhuraLipulekh,(p. 208-212) by Bhandari (2015). Kathmandu: Ratan Bhandari.

Risal, B. (1999, June 07). Limpiyadhura mathidubai tarphabat atikraman (in Nepali). Kantipur Daily. Kathmandu, Nepal.

Risal, B. (2015, June 11). "I am one who has involved officially from Nepal government in collecting sensus data in Limpiyadhura area in 1961". Naya Patrika Daily (Nepali).

Robinson, A. (1953). Elements of Cartography. New York: John Wiley \& Sons. doi:ISBN 978-0-471-72805-4. 
Jagat K. Bhusal / Evolution of cartographic aggression by India: A study of... Vol. 13: 47-68, 2020

Shrestha, B. N. (2000). Kalapani and Kalee ko Muhan (in Nepali). Kathmandu: Rastriya Janaprakashan.

Shrestha, B. N. (2003). Border Management of Nepal. Kathmandu: Bhumichitra Co. P. Ltd. Shrestha, H. L. (1999).Kalapani and kali ko muhan. Kathmandu: Rastriya Jana Prakasan.

Sodari, H. P. (Ed.). (2020). Anekaunka dristrima rastranirmatha (in Nepali). Kathmandu, Nepal: Editirial Board.

SOI. (1927). Map of Kumaun showing Forest Divisions in Jan 1924. http://pahar.in/ indian-subcontinent-pre-1899/ (January7, 2020). Retrieved from https://pahar. in/wpfb-file/1878-kumaun-and-british-garhwal-no-36-by-gts-jpg/.

Strachey, H. (1848). Map to Illustrate the Narrative of a Journey to the Lakes Rakas Tal and Manasorowar in Tibet, Reduced from the Original of Lt . H Strachey. 150170, 243-264; 394-415. Geogr. J, 15.

Survey of India. (1879, January). Surveyed during season 1973-74, 1874-75 and 1877. Kunmaun and British Garhwal. Dehra Dun, India: The office of the superintendent, Great Trigonometric Survey .

Survey of India. (1960). Northern frontiers of India. Scale 1:7 000000. Ministry of External Affairs, Government of India.

Survey of India. (2019, November 2 \& 8 ). Political Map of India. 8th Edition \& 9th Edition. Department of Science \& Technology. Retrieved from, http://www. surveyofindia.gov.in/pages/display/235-political-map-of-india.

Surveyor General of India. (1850, April). The Map of KUMAON and BRITISH GURHWAL. Culculta: Complied in the Office of the Surveyor General of India with the latest additions from H Strachey in 1846 and R Strachey in 1849. Retrieved from https:/pahar.in/indian-subcontinent-pre-1899/.

Surveyor General of India. (1961). Political Map of India . Boundary, International: India; Nepal; others, Sixth Edition (Scale 1 inch to 70 miles). Published under the direction of Colonel Rajinder Signh Kalha, M. I. S (Ind).

UP State Archives . (1911). District Gazetteers of the United Provinces of Agra and Oudh, vol-XXXV-Almora. Retrieved from Uttar Pradehs State Archives: http:// uparchives.up.nic.in/gazetters.aspx.

Webb, W. S. (1819). (The Survey of India offices (H L O)) Retrieved January 6, 2020, from The Sketch_of_Kumaon: https://upload.wikimedia.org/wikipedia/ commons/4/40/Sketch_of_Kumaon_\%28Survey_of_India\%29\%2C_1819.jpg.

Webb, W. S. (1819). Map of Province of Kumaon (jpg) . Retrieved from https://pahar.in/ indian-subcontinent-pre-1899/. 